OPEN ACCESS

Edited by:

Qin Yan,

Yale University, United States

Reviewed by:

Khaled Murshed,

Hamad Medical Corporation, Qatar

Dongdong Zhang,

Institute of Biophysics (CAS), China

*Correspondence:

Liang Weng

wengliang@csu.edu.cn

Yongshuo Liu

liuyongshuo@pku.edu.cn

Specialty section:

This article was submitted to

Cancer Immunity

and Immunotherapy,

a section of the journal

Frontiers in Immunology

Received: 12 June 2021

Accepted: 15 November 2021

Published: 30 November 2021

Citation:

Tang $X$, Sui $X$, Weng $L$ and

Liu Y (2021) SNAIL1: Linking Tumor

Metastasis to Immune Evasion.

Front. Immunol. 12:724200.

doi: 10.3389/fimmu.2021.724200

\title{
SNAIL1: Linking Tumor Metastasis to Immune Evasion
}

\begin{abstract}
Xiaolong Tang ${ }^{1}$, Xue Sui ${ }^{1}$, Liang Weng ${ }^{2,3,4,5,6,7 *}$ and Yongshuo Liu ${ }^{8,9 *}$
${ }^{1}$ Department of Laboratory Medicine, Binzhou Medical University, Binzhou, China, ${ }^{2}$ Department of Oncology, Xiangya Cancer Center, Xiangya Hospital, Central South University, Changsha, China, ${ }^{3}$ Key Laboratory of Molecular Radiation Oncology Hunan Province, Xiangya Hospital, Central South University, Changsha, China, ${ }^{4}$ Hunan International Science and Technology Collaboration Base of Precision Medicine for Cancer, Xiangya Hospital, Central South University, Changsha, China, ${ }^{5}$ Hunan Provincial Clinical Research Center for Respiratory Diseases, Xiangya Hospital, Central South University, Changsha, China, ${ }^{6}$ Institute of Gerontological Cancer Research, National Clinical Research Center for Gerontology, Changsha, China, ${ }^{7}$ Center for Molecular Imaging of Central South University, Xiangya Hospital, Changsha, China, ${ }^{8}$ Department of Clinical Laboratory, Binzhou Medical University Hospital, Binzhou, China, ${ }^{9}$ Biomedical Pioneering Innovation Center (BIOPIC), Beijing Advanced Innovation Center for Genomics, Peking-Tsinghua Center for Life Sciences, Peking University Genome Editing Research Center, State Key Laboratory of Protein and Plant Gene Research, School of Life Sciences, Peking University, Beijing, China
\end{abstract}

The transcription factor Snail1, a key inducer of epithelial-mesenchymal transition (EMT), plays a critical role in tumor metastasis. Its stability is strictly controlled by multiple intracellular signal transduction pathways and the ubiquitin-proteasome system (UPS). Increasing evidence indicates that methylation and acetylation of Snail1 also affects tumor metastasis. More importantly, Snail1 is involved in tumor immunosuppression by inducing chemokines and immunosuppressive cells into the tumor microenvironment (TME). In addition, some immune checkpoints potentiate Snail 1 expression, such as programmed death ligand 1 (PD-L1) and T cell immunoglobulin 3 (TIM-3). This mini review highlights the pathways and molecules involved in maintenance of Snail1 level and the significance of Snail1 in tumor immune evasion. Due to the crucial role of EMT in tumor metastasis and tumor immunosuppression, comprehensive understanding of Snail1 function may contribute to the development of novel therapeutics for cancer.

Keywords: Snail1, EMT, signaling pathway, ubiquitination, methylation, acetylation, tumor immunity

\section{INTRODUCTION}

Metastasis is one of the most prominent features of malignant tumors and is the leading cause of death in tumor patients (1). Tumor metastasis is a multi-step process in which EMT has a crucial regulatory role. During the process of EMT, epithelial cells lose their cell polarity and cell-cell adhesion, and transit to quasi-mesenchymal cell states, thus increasing their migration and invasion properties (2). Recent studies indicated that tumor progression and metastasis are closely related to epigenetic modifications and the immune system. It was reported that immune checkpoint molecules such as PD-L1 are involved in EMT regulation, while EMT can also induce immunosuppression and immune evasion in tumors (3).

The Snail family of zinc finger transcription factors comprises three members in vertebrates, Snail1 (Snail), Snail2 (Slug), Snail3 (Smuc) $(4,5)$. Snail1 and Snail2 down-regulate the expression of many target proteins associated with EMT. Among them, the most significant one is E-cadherin (6). 
Due to the critical role of Snaill in EMT, this mini review focuses on how appropriate Snaill levels are maintained in cells, with emphasis on the role of epigenetic and UPS in the regulation of Snail1. Furthermore, we also discuss the involvement of Snaill in tumor immune evasion, a role which has made it a promising therapeutics target in tumor treatment.

\section{STRUCTURAL AND FUNCTIONAL CHARACTERISTICS OF SNAIL1}

In all Snail family members, the amino terminal end contains a highly conserved SNAG domain, which functions as a transcriptional repressor domain (7). The fingers correspond to the $\mathrm{C} 2 \mathrm{H} 2$ type and bind to the upstream regulatory region of target genes for gene specific transcriptional inhibition (8). The central region of Snail2 includes the Slug domain, while Snail1 has two defined functional domains in this region: a regulatory domain containing an Xpo1/CRM1 mediated nuclear export signal (NES) (9) and a serine-rich domain involved in the regulation of its stability (10) (Figure 1A).

Snail1, as a transcriptional repressor, is implicated in the regulation of other tumor metastasis suppressors, such as the epithelial marker E-cadherin (11). Previous studies reported that SNAG domain of Snail1 couples on the CDH1 (which encodes Ecadherin) promoter (12), and recruits histone deacetylase
(HDAC). Subsequently, Snail1, HDAC1, HDAC2 and mSin3A conjointly form a multi-molecular complex that further inhibits the expression of E-cadherin (13). Furthermore, Snaill interacts with the H3K9 methyltransferase G9A or SUV39H1 and recruits it to the $\mathrm{CDH} 1$ promoter for transcriptional inhibition in breast cancer $(14,15)$, collectively resulting in the occurrence of EMT.

\section{THE SIGNALING PATHWAYS INVOLVED IN SNAIL1 EXPRESSION}

The expression of Snaill is regulated by many signaling pathways both at the transcriptional and protein level $(16,17)$ (Figure 1B). Physiologically, these signaling pathways control normal cell morphology, proliferation, differentiation, and apoptosis. However, abnormal activation of these signaling pathways contribute to the initiation and progression of tumors activated $(18,19)$.

\section{TGF- $\beta$ Pathway}

The transforming growth factor- $\beta$ (TGF- $\beta$ ) was described as an inducer of EMT during the development of tumor (20). Mechanistically, TGF- $\beta$ binds to its receptor T $\beta$ RII and T $\beta R I$, which subsequently phosphorylates its downstream targets, including members of the SMAD family of signal transducers, SMAD2 and SMAD3 (21), forming a heterooligomeric complex
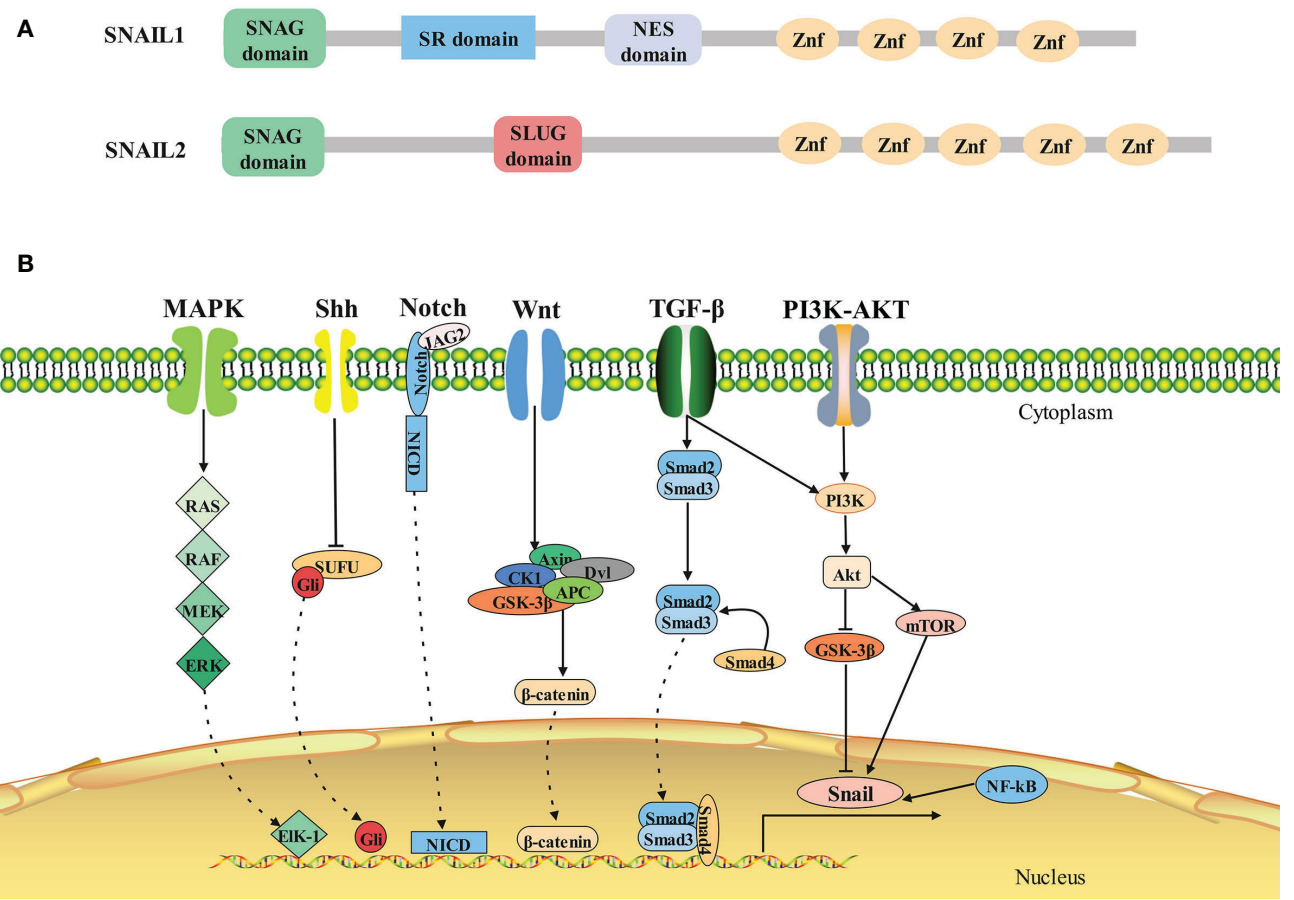

FIGURE 1 | Structure and signaling pathways of SNAIL1. (A)Architecture of SNAIL1 in human. Composite of the overall structure of Snail1 and Snail2, which shows the relative positions of the SNAG domain, the zinc fingers (I-V), and the Slug-specific boxes, NES domain and serine-rich domain. (B)The molecular signaling pathways of SNAIL1. Snail1 is regulated by several signaling pathways that promote its expression. From left to right: MAPK, Shh, Notch, Wnt, TGF- $\beta$, PI3K-AKT, and NF-KB signaling pathway. 
with SMAD4 (22). Then this SMAD complex translocates to the nucleus and functions as a transcription factor to regulate the transcription of target genes such as Snaill in human tumors (16, $21,23-25)$.

\section{PI3K-Akt Pathway}

The phosphatidylinositol 3-kinase (PI3K)-Akt signaling pathway is hyperactivated or altered in many cancer types (26-28) and regulates a broad range of cellular processes $(29,30)$. It is well known that Akt can phosphorylate and inhibit GSK-3 $\beta$ activity, subsequently suppressing the GSK-3 $\beta$-mediated phosphorylation of Snail 1 and facilitating its stabilization and nuclear localization, which ultimately promotes EMT widely presenting in a variety of tumors (31-36). In addition to GSK-3 $\beta$, PI3K-Akt also activates mTOR, thereby potentiating Snaill expression in gastric, breast, pancreatic and ovarian cancer (37-40). Furthermore, some studies also indicate TGF- $\beta$ regulates Snaill expression via the Akt/GSK-3 $\beta$ signaling pathway in osteosarcoma and ovarian clear cell carcinoma $(41,42)$.

\section{Wnt Pathway}

In the presence of Wnt signaling, the destruction complex (APC, Dvl, Axin, GSK-3 $\beta$, CK1) reduces the phosphorylation and ubiquitination of $\beta$-catenin (43).Thus, levels of cytoplasmic $\beta$-catenin rise, which translocates to the nucleus and induces transcription of pro-invasive factors (44-46). Moreover, $\beta$-catenin/T-cell factor (TCF) transcriptional complex regulates Snail1 via Axin2-mediated nuclear export of GSK-3 $\beta$ in breast cancer (47).

\section{Notch Pathway}

Notch signaling is generated through the interaction between Notch receptors and ligands such as Jagged-2 (JAG2) (48). Notch is released into the cytoplasm by intracellular segment (NICD) after being sheared three times (49), and then enters the nucleus to bind to the Snaill promoter, directly stimulating transcription (50).

\section{Shh Pathway}

Sonic Hedgehog (Shh) is a lipid-modified secreted protein that couples to Patched receptor (51). In the presence of Hedgehog signaling, Smoothened is relieved from Patched-mediated suppression due to the Hedgehog-dependent internalization of Patched, which leads to inactivation of SUFU for the stabilization and nuclear accumulation of Gli family members $(51,52)$. So far, Shh-mediated Glil activation was reported to induce the expression of Snaill in a variety of cancers, such as breast, skin, ovarian, pancreatic, neuroendocrine cancer and basal cell carcinoma (45, 53-57).

\section{MAPK Pathway}

The Ras/Raf/MEK/ERK pathway is the most important signaling cascade among all MAPK signal (58). Once activated, ERK translocates to the nucleus, binds to and regulates the activity of the transcription factor Elk-1 through phosphorylation (58). Of note, activation of Elk1 facilitates recruitment of phosphorylated mitogen and stress activated protein kinase 1
(MSK1), which in turn enhances histone $\mathrm{H} 3$ acetylation and phosphorylation (serine 10) of Snaill promoter, ultimately promoting the transcription of Snaill (59). Furthermore hepatocyte growth factor (HGF) could induce transcription of Snaill by activating MAPK signaling pathway in liver cancer (60).

\section{NF-kB Pathway}

The over-activation of nuclear factor- $\kappa \mathrm{B}(\mathrm{NF}-\kappa \mathrm{B})$ with a role in the inflammatory response, immune response and cell apoptosis, is associated with multifarious tumors (61). Previous studies have demonstrated that the activation of the NF- $\kappa B$ pathway blocked the degradation and promoted the transcription of Snail1 (62), subsequently facilitating the migration and invasion in breast, colorectal, gastric cancers, cholangiocarcinoma and malignant human keratinocyte (63-66).

\section{REGULATION OF SNAIL1 EXPRESSION BY UBIQUITIN-PROTEASOME STSTEM}

Ubiquitin mediates protein degradation via binding to lysine residues of the substrate proteins (67). It is highly conserved in eukaryotic cells and can also function as a signaling molecule to modulate protein function (68). Its eight residues including M1, K6, $\mathrm{K} 11, \mathrm{~K} 27, \mathrm{~K} 29, \mathrm{~K} 33, \mathrm{~K} 48$, and $\mathrm{K} 63$ are used as attachment sites to form polyubiquitin chains (69). The most abundant chain types are $\mathrm{K} 48$, which are usually degraded by the $26 \mathrm{~S}$ proteasome (68).

\section{Degradation of SNAIL1 by UPS}

Snail 1 is an extremely unstable protein, $\beta$-TrCP1 was first reported to be involved in Snail1 ubiquitination via GSK-3 $\beta$ mediated phosphorylation of S96 and S100 residues on Snail 1 (10). In contrast, Snail1 is ubiquitinated independently of GSK$3 \beta$ phosphorylation by FBXL14 through K98, 137, and 146 residues (70). Interestingly, miR-27a can directly downregulate the expression of FBXO45, resulting in reduced Snaill degradation (71). In breast cancer, the S11 residue of Snail1 is phosphorylated by PKD1, which promotes the ubiquitination and degradation of Snail1 by FBXO11 $(72,73)$, while FBXO22 depends on GSK-3 $\beta$ (74). In addition, it has been reported that PPIL2, SPSB3 and TRIM21 are involved in ubiquitination and degradation of Snaill (75-77). In gastric cancer, phosphorylation of Snaill is required for the F-box domain of FBXO31 to function (78), FBXW7 inhibits metastasis in part by binding to Snail1 (79) and FBXL5 promotes poly-ubiquitination of Snaill at K85, K146 and K234 residues $(80,81)$. In Non-small cell lung cancer, both $\beta$-TrCP2 and FBXW7 are absolutely implicated in ubiquitination and degradation of Snail1 $(82,83)$. In cervical cancer, HECTD1-mediated degradation of Snaill occurs in the cytoplasm rather than in the nucleus (84). Finally, other E3 ligases such as TRIM50 and CHIP, are also involved in regulation of Snail1 in hepatocarcinoma and ovarian cancer, respectively $(85,86)$.

So far, some molecular targets have been found based on the above E3 ligases, which are potential therapeutic targets. 
LINC00511 and EBV-miR-Bart10-3p both inhibit $\beta$-TrCP1 and prevent Snaill degradation in triple negative breast cancer and nasopharyngeal carcinoma, respectively $(87,88)$. In non-small cell lung cancer, the expression of the $\beta$-TrCP2 is inhibited by miR-106b-25 (83), while FBXW7 agonist (Oridonin) contributes to the degradation of Snail1 (89). In hepatocellular carcinoma, miR-1306-3p directly targets FBXL5 to suppress Snail1 degradation (90). Likewise, miR-27a immediately down-regulate the expression of FBXO45 (91). Particularly, BRD4 identifies acetylated K146 and K187 on Snail1 in an acetylation-dependent manner to prevent its degradation by FBXL14 and $\beta$-TrCP1 in gastric cancer (92). Inversely, Metformin is beneficial to the expression of LKB1, thereby strengthening the capacity of FBXL14 in pancreatic cancer (93) (Figure 2A).

\section{Stabilizing the Expression of SNAIL1 by DUBs}

Ubiquitination is a reversible process and ubiquitin moieties are removed from polypeptides by deubiquitinases (DUBs) (94). Currently, plentiful DUBs are involved in the occurrence, progression, and drug resistance of cancer (95-97). In esophageal squamous cell carcinoma, OTUB1 inhibits the ubiquitination and degradation of SMAD2/3, leading to strengthen TGF- $\beta$ signaling and stabilization of Snail 1 expression (98, 99). Interestingly, USP26 is a specific deubiquitinase of Snaill and significantly increases its stability by combining with the zinc finger domain at the Snaill, an essential region for its stability and nuclear localization (100, 101). In addition, EIF3H and PSMD14 have also been found to be involved in Snail1 deubiquitination (102, 103). In breast cancer, DUB3 couples on SNAG domain of Snaill and inhibits ubiquitination of Snail1 mediated by FBXL14 and $\beta$-TrCP1 (104). Analogously, CSN2 removes the ubiquitination of Snail1 via disrupting its binding to GSK-3 $\beta$ and $\beta$-TrCP (62). In lung cancer, CSN5 and USP37 significantly stabilize the expression of Snail1. More importantly, USP37 is closely associated with increased mortality and metastasis rates $(105,106)$. In glioblastoma, USP3 also hydrolyzes FBXO11 or FBXW1induced polyubiquitination chain on Snaill, resulting in increased aggressiveness and tumorigenicity (107). Similarly, high expression of OTUB1 in gliomas is associated with poor prognosis (108). In colorectal cancer, up-regulation of USP47 is mediated by SOX9, leading to an increase in Snaill deubiquitination under hypoxia condition (109). In gastric cancer, USP29 enhanced the interaction between Snail1 and SCP1, causing both dephosphorylation and deubiquitination of Snail1 (110).

\section{EPIGENETIC MODIFICATION IN SNAIL1 REGULATION}

Epigenetic abnormalities have been linked to many human diseases, including cancer $(111,112)$. Particularly, methylation and acetylation are involved in Snaill-mediated tumor metastasis (Figure 2A).

\section{Methylation of SNAIL1}

DNA methylation is an important mechanism of epigenetic gene regulation, which primarily occurs at $\mathrm{CpG}$ dinucleotide within gene promoters by a covalent modification of cytosine residues via DNA methyltransferase (DNMT) enzymes (113). It was previously reported that DNA methylation in the first intron region of Snail1 was negatively correlated with its transcription level, but its expression was increased when treated with DNMT inhibitor 5-Aza-2 '-deoxycytidine in trophoblast cells (114). Uniformly, the chromatin remodeling factor ARID2 represses EMT of hepatocellular carcinoma by recruiting DNMT1 to Snail1 promoter, which increases promoter methylation and inhibits its transcription (115). Recently, m6A RNA methylation is an emerging epigenetic modification, which has been associated with the progression of several cancers $(116,117)$. Interestingly, $\mathrm{m} 6 \mathrm{~A}$ is methylated by Methyltransferase-like 3 (METTL3) to accelerate Snaill expression in HeLa cells (118), which is equivalent to indirect regulation of Snail1 by methylation.

\section{Acetylation of SNAIL1}

Protein acetylation was originally discovered on histones in the nucleus and involved in gene transcription (119). Subsequently, non-histone proteins were increasingly found to also undergo acetylation (120). In nasopharyngeal carcinoma, the glucose metabolizing enzyme PDHE1 $\alpha$ facilitates H3K9 acetylation on the Snaill promoter to enhance cell motility and thereby drive cancer metastasis (121). Inversely, HOPX mediates epigenetic silencing of Snail1 transcription through the enhancement of histone H3K9 deacetylation in the Snaill promoter (122). In lung cancer cells, p300 acetylates Snaill at K187 (123), and CREBbinding protein (CBP) interacts with and acetylates Snaill at K146 and K187, which prevents formation of the repressor complex (124). As mentioned above, BRD4 recognizes acetylated K146 and K187 on Snail1 to prevent it from being degraded by E3 ligases in gastric cancer (92).

At present, histone deacetylase inhibitors (HDACIs) are now emerging as a new class of anticancer agents $(125,126)$. However, HDACIs stabilize surprisingly Snaill expression through several mechanisms in hepatocellular carcinoma: HDACIs up-regulate Snail1 at the transcriptional level by promoting SMAD2/3 phosphorylation and nuclear translocation (127). Posteriorly, HDACIs regulate the stabilization of Snaill via up-regulating the expression of CSN2, which interacts with Snail1 to expose its acetylation site, leading to inhibit degradation of Snaill via preventing its phosphorylation and ubiquitination (127). Coincidentally, this phenomenon was also observed in CNE2 cells (128). Accordingly, more cautions should be exercised in the usage of medicines such as HDACIs, as they may increase the risk of tumor metastasis.

\section{BIDIRECTIONAL REGULATION OF SNAIL1 AND TUMOR IMMUNE ENVIRONMENT IN TUMOR PROGRESSION}

Tumorigenesis and progression are influenced by tumor microenvironment and controlled by the host immune system 

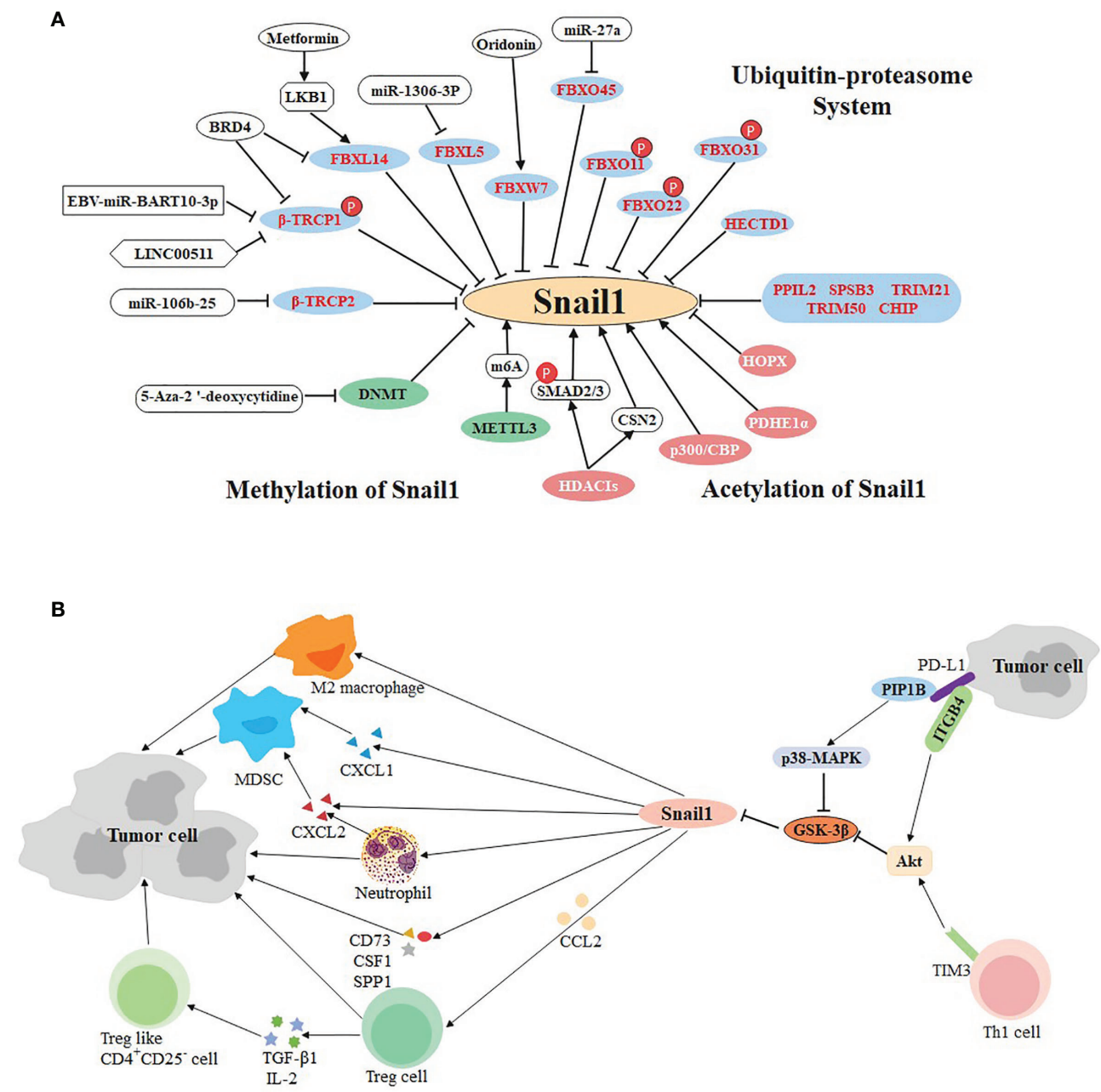

Tumor microenvironment

Immunosuppressive checkpoints

FIGURE 2 | Multifaceted regulation of SNAIL1. (A) Ubiquitination, methylation, and acetylation regulate the expression of SNAIL1. The ubiquitin E3 ligases in the blue circle negatively regulate the expression of Snail1. Small molecule compounds or drugs directly or indirectly act on E3 ligase to promote or inhibit the expression of Snail1. Molecules in the green and pink circles participate in methylation and acetylation of Snail1, respectively. (B) Bidirectional regulation of SNAlL1 and tumor immune environment. Snail1 recruits immunosuppressive cells (including Treg, MDSCs, M2 macrophages, neutrophils, and Treg-like CD4+CD25- cells) to participate in the formation of tumor microenvironment via cytokines, chemokines and their receptors. In addition, immunosuppressive checkpoints PD-L1 and TIM-3 can regulate the expression of Snail1 through different molecular pathways.

(129). In addition to malignant cells, adipocytes, fibroblasts, tumor vasculature, lymphocytes, dendritic cells, and cancer-associated fibroblasts are present in the tumor microenvironment (130). The last decade has witnessed dramatic advances in cancer treatment through immunotherapy such as immune checkpoints inhibitors, which are the most popular and promising treatment at present (131). Recently, the bidirectional regulation of immune checkpoints and EMT was uncovered via Snail1 (Figure 2B).

\section{Immunosuppressive Checkpoints Regulate SNAIL1 Expression}

So far, two immune checkpoint proteins PD-L1 and TIM-3 have been found to regulate Snaill expression. PD-L1, which accumulates to high level on the surface of some tumor cells, can bind to PD-1 and induce T cells exhaustion, thereby mediating tumor immune escape and potentiating tumor progression (132, 133). Histochemical staining of 477 lung adenocarcinoma specimens showed a positive correlation between the expression of PD-L1 and Snail1 (134). Two studies showed that PD-L1 can inhibit GSK3 $\beta$ activity via binding to tyrosine phosphatase PTP1B or integrin $\beta 4$ to activate p38-MAPK or Akt activity, respectively. Through this mechanism, PD-L1 can inhibit GSK3 $\beta$-mediated phosphorylation, ubiquitination, and degradation of Snail1, thereby promoting EMT and the metastatic potential of breast cancer and cervical cancer $(135,136)$.

TIM-3 contains an immunoglobulin and a mucin-like domain and was originally identified as a receptor expressed on Th1 cells (137). The silencing of TIM-3 was accompanied by a 
decrease in Snaill expression, indicating that TIM-3 may be involved in metastasis of osteosarcoma and hepatocellular carcinoma (138-140). Due to the lack of research in this aspect, it is only known that TIM-3 induces EMT to stimulate the metastasis of esophageal squamous cell carcinoma at least partly through the Akt/GSK-3ß/Snail1 signaling pathway (141).

\section{The role of SNAIL1 in Tumor Immune Evasion}

Increasing evidence suggests that Snaill is also involved in immune escape from tumors, which can accelerate cancer metastasis. Previous research has reported the quantity of tumor-specific infiltrating lymphocytes and the systemic immune response increased via silencing Snaill in melanoma (142), suggesting that Snail1 is visibly involved in tumor immunity. Firstly, Snail1 recruits CD4+FOXP3+Treg cells into the tumor microenvironment through C-C motif chemokine ligand 2 (CCL2) (143). In a mouse model of lung cancer, Snaill was also found to increase intratumoral C-X-C chemokine ligand 2 (CXCL2) secretion and neutrophil infiltration (144). In ovarian cancer, Snaill accelerates cancer progression via up-regulation of CXCL1 and CXCL2 as well as recruitment of myeloid-derived suppressor cells (MDSCs) (145), which plays a vital role in cancer immunosuppression, tumor angiogenesis, drug resistance and promotion of tumor metastasis (146, 147). In cholangiocarcinoma, Snaill appears to produce immunosuppressive natural T-regulatory like CD4+CD25- cells, in part by mediating the $\mathrm{T}$ regulatory-inducible cytokines such as TGF- $\beta 1$ and IL-2 (148). In addition, Snail1 induces M2 polarization of tumor-associated macrophages and facilitates tumor growth in head and neck cancer (149). A recent study showed that the high expression of Snaill in mesenchymal tumor cell induces the expression of several cytokines (CD73, CSF1, SPP1), which collectively expedites the assembly of tumor immunosuppressive microenvironments (2). All these lines of evidence strongly confirm that Snaill effectively promotes tumor cells to secrete chemokines or cytokines, which recruits various immunosuppressive cells to the tumor microenvironment and provides an appropriate environment for tumor metastasis.

\section{SUMMARY AND FUTURE PERSPECTIVES}

Physiologically, Snaill participates in embryo implantation and initiation, wound healing, and cell survival $(8,150,151)$. In addition, as we discussed above, Snaill is a crucial target involved in tumor metastasis and immune escape, and can endow tumor cells with the characteristics of stem cells (5). What's more, Snaill overexpression was found to be a potential risk factor of neoplasm recurrence in

\section{REFERENCES}

1. Lin $\mathrm{Y}, \mathrm{Xu}$ J, Lan H. Tumor-Associated Macrophages in Tumor Metastasis: Biological Roles and Clinical Therapeutic Applications. J Hematol Oncol (2019) 12:76. doi: 10.1186/s13045-019-0760-3

2. Dongre A, Rashidian M, Eaton EN, Reinhardt F, Thiru P, Zagorulya $\mathrm{M}$, et al. Direct and Indirect Regulators of Epithelial-Mesenchymal Transition-Mediated Immunosuppression in Breast Carcinomas. various cancers, such as cutaneous squamous cell carcinoma, clear cell renal cell carcinoma, ameloblastic carcinoma, non-muscleinvasive bladder, colon and non-small-cell lung cancer (152-157). Consistent with tumor relapse, Snaill overexpression also indicates poor prognosis in several types of cancers (158-161). Taken together, Snaill can function as a biomarker to predict tumor relapse and patient prognosis.

Snaill also hold critical role in cancer treatment, increasing evidence suggested that Snaill is implicated in chemotherapy and radiotherapy resistance. For instance, silencing Snail1 was found to be beneficial in enhancing the sensitivity of gemcitabine therapy in pancreatic ductal carcinoma $(162,163)$ and increasing radiosensitivity in hypopharyngeal carcinoma (164). Furthermore, Snaill contributes to the resistance of glioblastoma cells to temozolomide via the IL-6-STAT3-Snaill pathway (165) and colorectal cancer cells to 5-fluorouracil by facilitating the expression of the ABCB1 resistance gene (166). In addition, Snaill overexpression could induce tumor stem cell-like phenotype and generate chemotherapy resistance to oxaliplatin in colorectal cancer (167). Collectively, chemotherapy or radiotherapy combined with Snaill inhibitors such as CYD19 (168), GN-25 (169) and Co (III)-Ebox (170) may be a promising therapeutic approach to combat tumors. At present, it has not yet been reported whether Snaill is involved in immune checkpoint blockade. Due to knockdown of Snaill decreases the infiltration of immunosuppressive cells in the tumor microenvironment, it is possible targeting Snaill could enhance the anti-tumor effect. Accordingly, further development of novel Snail1 inhibitors and investigation of the safety of these compounds is urgently need for conquering cancer in future.

\section{AUTHOR CONTRIBUTIONS}

$\mathrm{XT}$ and XS were responsible for the primary review of literature, consolidation of information, and writing. LW and YL guided and supervised this study. All authors contributed to the article and approved the submitted version.

\section{FUNDING}

This work was supported by National Natural Science Foundations of China (81802400 to YL, 81900199 and 81974465 to LW), China Postdoctoral Science Foundation (2020M670053 to YL), Hunan province natural science funds for Excellent Young Scholars (2019JJ30043 to LW) and the recruitment program for Huxiang talents (2019RS1009 to LW). 
5. Wang Y, Shi J, Chai K, Ying X, Zhou BP. The Role of Snail in EMT and Tumorigenesis. Curr Cancer Drug Targets (2013) 13:963-72. doi: 10.2174/ 15680096113136660102

6. Whiteman EL, Liu CJ, Fearon ER, Margolis B. The Transcription Factor Snail Represses Crumbs3 Expression and Disrupts Apico-Basal Polarity Complexes. Oncogene (2008) 27:3875-9. doi: 10.1038/onc.2008.9

7. Chiang C, Ayyanathan K. Snail/Gfi-1 (SNAG) Family Zinc Finger Proteins in Transcription Regulation, Chromatin Dynamics, Cell Signaling, Development, and Disease. Cytokine Growth Factor Rev (2013) 24:123-31. doi: 10.1016/j.cytogfr.2012.09.002

8. Nieto MA. The Snail Superfamily of Zinc-Finger Transcription Factors. Nat Rev Mol Cell Biol (2002) 3:155-66. doi: 10.1038/nrm757

9. Dominguez D, Montserrat-Sentis B, Virgos-Soler A, Guaita S, Grueso J, Porta M, et al. Phosphorylation Regulates the Subcellular Location and Activity of the Snail Transcriptional Repressor. Mol Cell Biol (2003) 23:5078-89. doi: 10.1128/MCB.23.14.5078-5089.2003

10. Zhou BP, Deng J, Xia W, Xu J, Li YM, Gunduz M, et al. Dual Regulation of Snail by GSK-3beta-Mediated Phosphorylation in Control of EpithelialMesenchymal Transition. Nat Cell Biol (2004) 6:931-40. doi: 10.1038/ ncb1173

11. Hanahan D, Weinberg RA. Hallmarks of Cancer: The Next Generation. Cell (2011) 144:646-74. doi: 10.1016/j.cell.2011.02.013

12. Gall TM, Frampton AE. Gene of the Month: E-Cadherin (CDH1). J Clin Pathol (2013) 66:928-32. doi: 10.1136/jclinpath-2013-201768

13. Peinado H, Ballestar E, Esteller M, Cano A. Snail Mediates E-Cadherin Repression by the Recruitment of the Sin3A/histone Deacetylase 1 (HDAC1)/HDAC2 Complex. Mol Cell Biol (2004) 24:306-19. doi: 10.1128/MCB.24.1.306-319.2004

14. Dong C, Wu Y, Yao J, Wang Y, Yu Y, Rychahou PG, et al. G9a Interacts With Snail and is Critical for Snail-Mediated E-Cadherin Repression in Human Breast Cancer. J Clin Invest (2012) 122:1469-86. doi: 10.1172/ JCI57349

15. Dong C, Wu Y, Wang Y, Wang C, Kang T, Rychahou PG, et al. Interaction With Suv39H1 is Critical for Snail-Mediated E-Cadherin Repression in Breast Cancer. Oncogene (2013) 32:1351-62. doi: 10.1038/onc.2012.169

16. Odero-Marah V, Hawsawi O, Henderson V, Sweeney J. EpithelialMesenchymal Transition (EMT) and Prostate Cancer. Adv Exp Med Biol (2018) 1095:101-10. doi: 10.1007/978-3-319-95693-0_6

17. Vu T, Datta PK. Regulation of EMT in Colorectal Cancer: A Culprit in Metastasis. Cancers (Basel) (2017) 9:171. doi: 10.3390/cancers9120171

18. Nieszporek A, Skrzypek K, Adamek G, Majka M. Molecular Mechanisms of Epithelial to Mesenchymal Transition in Tumor Metastasis. Acta Biochim Pol (2019) 66:509-20. doi: 10.18388/abp.2019_2899

19. Liu X, Yun F, Shi L, Li ZH, Luo NR, Jia YF. Roles of Signaling Pathways in the Epithelial-Mesenchymal Transition in Cancer. Asian Pac J Cancer Prev (2015) 16:6201-6. doi: 10.7314/apjcp.2015.16.15.6201

20. Xu J, Lamouille S, Derynck R. TGF-Beta-Induced Epithelial to Mesenchymal Transition. Cell Res (2009) 19:156-72. doi: 10.1038/cr.2009.5

21. Miyazono K. Transforming Growth Factor-Beta Signaling in EpithelialMesenchymal Transition and Progression of Cancer. Proc Jpn Acad Ser B Phys Biol Sci (2009) 85:314-23. doi: 10.2183/pjab.85.314

22. Vincent T, Neve EP, Johnson JR, Kukalev A, Rojo F, Albanell J, et al. A SNAIL1-SMAD3/4 Transcriptional Repressor Complex Promotes TGF-Beta Mediated Epithelial-Mesenchymal Transition. Nat Cell Biol (2009) 11:94350. doi: $10.1038 / \mathrm{ncb} 1905$

23. Jiang X, Zhang Z, Song C, Deng H, Yang R, Zhou L, et al. Glaucocalyxin A Reverses EMT and TGF-Beta1-Induced EMT by Inhibiting TGF-Beta1/ Smad2/3 Signaling Pathway in Osteosarcoma. Chem Biol Interact (2019) 307:158-66. doi: 10.1016/j.cbi.2019.05.005

24. Tong X, Wang S, Lei Z, Li C, Zhang C, Su Z, et al. MYOCD and SMAD3/ SMAD4 Form a Positive Feedback Loop and Drive TGF-Beta-Induced Epithelial-Mesenchymal Transition in Non-Small Cell Lung Cancer. Oncogene (2020) 39:2890-904. doi: 10.1038/s41388-020-1189-4

25. Li C, Ao H, Chen G, Wang F, Li F. The Interaction of CDH20 With BetaCatenin Inhibits Cervical Cancer Cell Migration and Invasion via TGF-Beta/ Smad/SNAIL Mediated EMT. Front Oncol (2019) 9:1481. doi: 10.3389/ fonc.2019.01481
26. Costa R, Han HS, Gradishar WJ. Targeting the PI3K/AKT/mTOR Pathway in Triple-Negative Breast Cancer: A Review. Breast Cancer Res Treat (2018) 169:397-406. doi: 10.1007/s10549-018-4697-y

27. Chen H, Zhou L, Wu X, Li R, Wen J, Sha J, et al. The PI3K/AKT Pathway in the Pathogenesis of Prostate Cancer. Front Biosci (Landmark Ed) (2016) 21:1084-91. doi: $10.2741 / 4443$

28. Marquard FE, Jucker M. PI3K/AKT/mTOR Signaling as a Molecular Target in Head and Neck Cancer. Biochem Pharmacol (2020) 172:113729. doi: $10.1016 /$ j.bcp.2019.113729

29. Ersahin T, Tuncbag N, Cetin-Atalay R. The PI3K/AKT/mTOR Interactive Pathway. Mol Biosyst (2015) 11:1946-54. doi: 10.1039/c5mb00101c

30. Porta C, Paglino C, Mosca A. Targeting PI3K/Akt/mTOR Signaling in Cancer. Front Oncol (2014) 4:64. doi: 10.3389/fonc.2014.00064

31. Zhao GX, Xu YY, Weng SQ, Zhang S, Chen Y, Shen XZ, et al. CAPS1 Promotes Colorectal Cancer Metastasis via Snail Mediated Epithelial Mesenchymal Transformation. Oncogene (2019) 38:4574-89. doi: 10.1038/ s41388-019-0740-7

32. Liu JJ, Li LZ, Xu P. Upregulation of TRPM8 can Promote the Colon Cancer Liver Metastasis Through Mediating Akt/GSK-3 Signal Pathway. Biotechnol Appl Biochem (2021) 0:1-10. doi: 10.1002/bab.2102

33. Lan Y, Han J, Wang Y, Wang J, Yang G, Li K, et al. STK17B Promotes Carcinogenesis and Metastasis via AKT/GSK-3beta/Snail Signaling in Hepatocellular Carcinoma. Cell Death Dis (2018) 9:236. doi: 10.1038/ s41419-018-0262-1

34. Liu H, Xu L, He H, Zhu Y, Liu J, Wang S, et al. Hepatitis B Virus X Protein Promotes Hepatoma Cell Invasion and Metastasis by Stabilizing Snail Protein. Cancer Sci (2012) 103:2072-81. doi: 10.1111/cas.12017

35. Gao Y, Zheng H, Li L, Zhou C, Chen X, Zhou X, et al. KIF3C Promotes Proliferation, Migration, and Invasion of Glioma Cells by Activating the PI3K/AKT Pathway and Inducing EMT. BioMed Res Int (2020) 2020:6349312. doi: 10.1155/2020/6349312

36. Chen L, Wu Q, Xu X, Yang C, You J, Chen F, et al. Cancer/testis Antigen LDHC Promotes Proliferation and Metastasis by Activating the PI3K/Akt/ GSK-3beta-Signaling Pathway and the in Lung Adenocarcinoma. Exp Cell Res (2021) 398:112414. doi: 10.1016/j.yexcr.2020.112414

37. Wu YJ, Lin SH, Din ZH, Su JH, Liu CI. Sinulariolide Inhibits Gastric Cancer Cell Migration and Invasion Through Downregulation of the EMT Process and Suppression of FAK/PI3K/AKT/mTOR and MAPKs Signaling Pathways. Mar Drugs (2019) 17:668. doi: 10.3390/md17120668

38. Cheng Y, Pan Y, Pan Y, Wang O. MNX1-AS1 is a Functional Oncogene That Induces EMT and Activates the AKT/mTOR Pathway and MNX1 in Breast Cancer. Cancer Manag Res (2019) 11:803-12. doi: 10.2147/ CMAR.S188007

39. Sharma N, Nanta R, Sharma J, Gunewardena S, Singh KP, Shankar S, et al. PI3K/AKT/mTOR and Sonic Hedgehog Pathways Cooperate Together to Inhibit Human Pancreatic Cancer Stem Cell Characteristics and Tumor Growth. Oncotarget (2015) 6:32039-60. doi: 10.18632/oncotarget.5055

40. Lau MT, Leung PC. The PI3K/Akt/mTOR Signaling Pathway Mediates Insulin-Like Growth Factor 1-Induced E-Cadherin Down-Regulation and Cell Proliferation in Ovarian Cancer Cells. Cancer Lett (2012) 326:191-8. doi: 10.1016/j.canlet.2012.08.016

41. Yu B, Jiang K, Zhang J. MicroRNA-124 Suppresses Growth and Aggressiveness of Osteosarcoma and Inhibits TGF-Beta-Mediated AKT/ GSK-3beta/SNAIL-1 Signaling. Mol Med Rep (2018) 17:6736-44. doi: $10.3892 / \mathrm{mmr} .2018 .8637$

42. Matsumoto T, Yokoi A, Hashimura M, Oguri Y, Akiya M, Saegusa M. TGFBeta-Mediated LEFTY/Akt/GSK-3beta/Snail Axis Modulates EpithelialMesenchymal Transition and Cancer Stem Cell Properties in Ovarian Clear Cell Carcinomas. Mol Carcinog (2018) 57:957-67. doi: 10.1002/mc.22816

43. Schaefer KN, Peifer M. Wnt/Beta-Catenin Signaling Regulation and a Role for Biomolecular Condensates. Dev Cell (2019) 48:429-44. doi: 10.1016/ j.devcel.2019.01.025

44. Clevers H, Nusse R. Wnt/beta-Catenin Signaling and Disease. Cell (2012) 149:1192-205. doi: 10.1016/j.cell.2012.05.012

45. Li X, Deng W, Lobo-Ruppert SM, Ruppert JM. Glil Acts Through Snail and E-Cadherin to Promote Nuclear Signaling by Beta-Catenin. Oncogene (2007) 26:4489-98. doi: 10.1038/sj.onc.1210241 
46. Schmalhofer O, Brabletz S. Brabletz T. E-Cadherin, Beta-Catenin, and ZEB1 in Malignant Progression of Cancer. Cancer Metastasis Rev (2009) 28:15166. doi: 10.1007/s10555-008-9179-y

47. Yook JI, Li XY, Ota I, Hu C, Kim HS, Kim NH, et al. Weiss SJ. A Wnt-Axin2GSK3beta Cascade Regulates Snaill Activity in Breast Cancer Cells. Nat Cell Biol (2006) 8:1398-406. doi: 10.1038/ncb1508

48. Houde C, Li Y, Song L, Barton K, Zhang Q, Godwin J, et al. Overexpression of the NOTCH Ligand JAG2 in Malignant Plasma Cells From Multiple Myeloma Patients and Cell Lines. Blood (2004) 104:3697-704. doi: 10.1182/ blood-2003-12-4114

49. Kopan R, Ilagan MX. The Canonical Notch Signaling Pathway: Unfolding the Activation Mechanism. Cell (2009) 137:216-33. doi: 10.1016/ j.cell.2009.03.045

50. Wang Z, Li Y, Kong D, Sarkar FH. The Role of Notch Signaling Pathway in Epithelial-Mesenchymal Transition (EMT) During Development and Tumor Aggressiveness. Curr Drug Targets (2010) 11:745-51. doi: 10.2174/ 138945010791170860

51. Carballo GB, Honorato JR, de Lopes G, Spohr T. A Highlight on Sonic Hedgehog Pathway. Cell Commun Signal (2018) 16:11. doi: 10.1186/s12964018-0220-7

52. Katoh Y, Katoh M. Hedgehog Signaling, Epithelial-to-Mesenchymal Transition and miRNA (Review). Int J Mol Med (2008) 22:271-5. doi: 10.3892/ijmm_00000019

53. Riaz SK, Ke Y, Wang F, Kayani MA, Malik M. Influence of SHH/GLI1 Axis on EMT Mediated Migration and Invasion of Breast Cancer Cells. Sci Rep (2019) 9:6620. doi: 10.1038/s41598-019-43093-x

54. Ke Z, Caiping S, Qing Z, Xiaojing W. Sonic Hedgehog-Gli1 Signals Promote Epithelial-Mesenchymal Transition in Ovarian Cancer by Mediating PI3K/ AKT Pathway. Med Oncol (2015) 32:368. doi: 10.1007/s12032-014-0368-y

55. Feldmann G, Dhara S, Fendrich V, Bedja D, Beaty R, Mullendore M, et al. Blockade of Hedgehog Signaling Inhibits Pancreatic Cancer Invasion and Metastases: A New Paradigm for Combination Therapy in Solid Cancers. Cancer Res (2007) 67:2187-96. doi: 10.1158/0008-5472.CAN-06-3281

56. Fendrich V, Waldmann J, Esni F, Ramaswamy A, Mullendore M, Buchholz M, et al. Snail and Sonic Hedgehog Activation in Neuroendocrine Tumors of the Ileum. Endocr Relat Cancer (2007) 14:865-74. doi: 10.1677/ERC-07-0108

57. Li X, Deng W, Nail CD, Bailey SK, Kraus MH, Ruppert JM, et al. Snail Induction is an Early Response to Gli1 That Determines the Efficiency of Epithelial Transformation. Oncogene (2006) 25:609-21. doi: 10.1038/ sj.onc. 1209077

58. Guo YJ, Pan WW, Liu SB, Shen ZF, Xu Y, Hu LL. ERK/MAPK Signalling Pathway and Tumorigenesis. Exp Ther Med (2020) 19:1997-2007. doi: 10.3892/etm.2020.8454

59. Hsu YL, Hou MF, Kuo PL, Huang YF, Tsai EM. Breast Tumor-Associated Osteoblast-Derived CXCL5 Increases Cancer Progression by ERK/MSK1/ Elk-1/Snail Signaling Pathway. Oncogene (2013) 32:4436-47. doi: 10.1038/ onc.2012.444

60. Grotegut S, von Schweinitz D, Christofori G, Lehembre F. Hepatocyte Growth Factor Induces Cell Scattering Through MAPK/Egr-1-Mediated Upregulation of Snail. EMBO J (2006) 25:3534-45. doi: 10.1038/ sj.emboj.7601213

61. Dolcet X, Llobet D, Pallares J, Matias-Guiu X. NF-kB in Development and Progression of Human Cancer. Virchows Arch (2005) 446:475-82. doi: $10.1007 / \mathrm{s} 00428-005-1264-9$

62. Wu Y, Deng J, Rychahou PG, Qiu S, Evers BM, Zhou BP. Stabilization of Snail by NF-kappaB is Required for Inflammation-Induced Cell Migration and Invasion. Cancer Cell (2009) 15:416-28. doi: 10.1016/j.ccr.2009.03.016

63. Yang Y, Li Y, Wang K, Wang Y, Yin W, Li L. P38/NF-Kappab/Snail Pathway is Involved in Caffeic Acid-Induced Inhibition of Cancer Stem Cells-Like Properties and Migratory Capacity in Malignant Human Keratinocyte. PloS One (2013) 8:e58915. doi: 10.1371/journal.pone.0058915

64. Zhang K, Zhaos J, Liu X, Yan B, Chen D, Gao Y, et al. Activation of NF-B Upregulates Snail and Consequent Repression of E-Cadherin in Cholangiocarcinoma Cell Invasion. Hepatogastroenterology (2011) 58:1-7. doi: 10.1186/1746-160X-7-15

65. Zhu QC, Gao RY, Wu W, Qin HL. Epithelial-Mesenchymal Transition and Its Role in the Pathogenesis of Colorectal Cancer. Asian Pac J Cancer Prev (2013) 14:2689-98. doi: 10.7314/apjcp.2013.14.5.2689
66. Li J, Deng Z, Wang Z, Wang D, Zhang L, Su Q, et al. Zipper-Interacting Protein Kinase Promotes Epithelial-Mesenchymal Transition, Invasion and Metastasis Through AKT and NF-kB Signaling and Is Associated With Metastasis and Poor Prognosis in Gastric Cancer Patients. Oncotarget (2015) 6:8323-38. doi: 10.18632/oncotarget. 3200

67. Swatek KN, Komander D. Ubiquitin Modifications. Cell Res (2016) 26:399422. doi: $10.1038 /$ cr.2016.39

68. Nandi D, Tahiliani P, Kumar A, Chandu D. The Ubiquitin-Proteasome System. J Biosci (2006) 31:137-55. doi: 10.1007/BF02705243

69. Wu X, Luo Q, Liu Z. Ubiquitination and Deubiquitination of MCL1 in Cancer: Deciphering Chemoresistance Mechanisms and Providing Potential Therapeutic Options. Cell Death Dis (2020) 11:556. doi: 10.1038/s41419020-02760-y

70. Vinas-Castells R, Beltran M, Valls G, Gomez I, Garcia JM, Montserrat-Sentis B, et al. The Hypoxia-Controlled FBXL14 Ubiquitin Ligase Targets SNAIL1 for Proteasome Degradation. J Biol Chem (2010) 285:3794-805. doi: 10.1074/jbc.M109.065995

71. Xu M, Zhu C, Zhao X, Chen C, Zhang H, Yuan H, et al. Atypical Ubiquitin E3 Ligase Complex Skp1-Pam-Fbxo45 Controls the Core Epithelial-toMesenchymal Transition-Inducing Transcription Factors. Oncotarget (2015) 6:979-94. doi: 10.18632/oncotarget.2825

72. Jin Y, Shenoy AK, Doernberg S, Chen H, Luo H, Shen H, et al. FBXO11 Promotes Ubiquitination of the Snail Family of Transcription Factors in Cancer Progression and Epidermal Development. Cancer Lett (2015) 362:70-82. doi: 10.1016/j.canlet.2015.03.037

73. Zheng H, Shen M, Zha YL, Li W, Wei Y, Blanco MA, et al. PKD1 Phosphorylation-Dependent Degradation of SNAIL by SCF-FBXO11 Regulates Epithelial-Mesenchymal Transition and Metastasis. Cancer Cell (2014) 26:358-73. doi: 10.1016/j.ccr.2014.07.022

74. Sun R, Xie HY, Qian JX, Huang YN, Yang F, Zhang FL, et al. FBXO22 Possesses Both Protumorigenic and Antimetastatic Roles in Breast Cancer Progression. Cancer Res (2018) 78:5274-86. doi: 10.1158/0008-5472.CAN17-3647

75. Jia Z, Wang M, Li S, Li X, Bai XY, Xu Z, et al. Wu H. U-Box Ubiquitin Ligase PPIL2 Suppresses Breast Cancer Invasion and Metastasis by Altering Cell Morphology and Promoting SNAI1 Ubiquitination and Degradation. Cell Death Dis (2018) 9:63. doi: 10.1038/s41419-017-0094-4

76. Liu Y, Zhou H, Zhu R, Ding F, Li Y, Cao X, et al. SPSB3 Targets SNAIL for Degradation in GSK-3beta Phosphorylation-Dependent Manner and Regulates Metastasis. Oncogene (2018) 37:768-76. doi: 10.1038/onc.2017.370

77. Jin Y, Zhang Y, Li B, Zhang J, Dong Z, Hu X, et al. TRIM21 Mediates Ubiquitination of Snail and Modulates Epithelial to Mesenchymal Transition in Breast Cancer Cells. Int J Biol Macromol (2019) 124:846-53. doi: 10.1016/j.ijbiomac.2018.11.269

78. Zou S, Ma C, Yang F, Xu X, Jia J, Liu Z. FBXO31 Suppresses Gastric Cancer EMT by Targeting Snaill for Proteasomal Degradation. Mol Cancer Res (2018) 16:286-95. doi: 10.1158/1541-7786.MCR-17-0432

79. Li H, Wang Z, Zhang W, Qian K, Xu W, Zhang S. Fbxw7 Regulates Tumor Apoptosis, Growth Arrest and the Epithelial-to-Mesenchymal Transition in Part Through the RhoA Signaling Pathway in Gastric Cancer. Cancer Lett (2016) 370:39-55. doi: 10.1016/j.canlet.2015.10.006

80. Wu W, Ding H, Cao J, Zhang W. FBXL5 Inhibits Metastasis of Gastric Cancer Through Suppressing Snail1. Cell Physiol Biochem (2015) 35:176472. doi: $10.1159 / 000373988$

81. Vinas-Castells R, Frias A, Robles-Lanuza E, Zhang K, Longmore GD, Garcia DHA, et al. Nuclear Ubiquitination by FBXL5 Modulates Snaill DNA Binding and Stability. Nucleic Acids Res (2014) 42:1079-94. doi: 10.1093/nar/gkt935

82. Xiao G, Li Y, Wang M, Li X, Qin S, Sun X, et al. FBXW7 Suppresses Epithelial-Mesenchymal Transition and Chemo-Resistance of Non-SmallCell Lung Cancer Cells by Targeting Snail for Ubiquitin-Dependent Degradation. Cell Prolif (2018) 51:e12473. doi: 10.1111/cpr.12473

83. Savita U, Karunagaran D. MicroRNA-106b-25 Cluster Targets Beta-TRCP2, Increases the Expression of Snail and Enhances Cell Migration and Invasion in H1299 (Non Small Cell Lung Cancer) Cells. Biochem Biophys Res Commun (2013) 434:841-7. doi: 10.1016/j.bbrc.2013.04.025

84. Wang X, De Geyter C, Jia Z, Peng Y, Zhang H. HECTD1 Regulates the Expression of SNAIL: Implications for Epithelialmesenchymal Transition. Int J Oncol (2020) 56:1186-98. doi: 10.3892/ijo.2020.5002 
85. Ma X, Ma X, Qiu Y, Zhu L, Lin Y, You Y, et al. TRIM50 Suppressed Hepatocarcinoma Progression Through Directly Targeting SNAIL for Ubiquitous Degradation. Cell Death Dis (2018) 9:608. doi: 10.1038/ s41419-018-0644-4

86. Park SM, Park SH, Ryu KJ, Kim IK, Han H, Kim HJ, et al. Downregulation of CHIP Promotes Ovarian Cancer Metastasis by Inducing Snail-Mediated Epithelial-Mesenchymal Transition. Mol Oncol (2019) 13:1280-95. doi: 10.1002/1878-0261.12485

87. Liu R, Wang L, Gan T, Pan T, Huang J, Bai M. Long Noncoding RNA LINC00511 Promotes Cell Growth and Invasion in Triple-Negative Breast Cancer by Interacting With Snail. Cancer Manag Res (2019) 11:5691-9. doi: 10.2147/CMAR.S203455

88. Yan Q, Zeng Z, Gong Z, Zhang W, Li X, He B, et al. EBV-miR-BART10-3p Facilitates Epithelial-Mesenchymal Transition and Promotes Metastasis of Nasopharyngeal Carcinoma by Targeting BTRC. Oncotarget (2015) 6:41766-82. doi: 10.18632/oncotarget.6155

89. Zhang Y, Zhang X, Ye M, Jing P, Xiong J, Han Z, et al. FBW7 Loss Promotes Epithelial-to-Mesenchymal Transition in Non-Small Cell Lung Cancer Through the Stabilization of Snail Protein. Cancer Lett (2018) 419:75-83. doi: 10.1016/j.canlet.2018.01.047

90. He ZJ, Li W, Chen H, Wen J, Gao YF, Liu YJ. miR-1306-3p Targets FBXL5 to Promote Metastasis of Hepatocellular Carcinoma Through Suppressing Snail Degradation. Biochem Biophys Res Commun (2018) 504:820-6. doi: 10.1016/j.bbrc.2018.09.059

91. Lin M, Wang ZW, Zhu X. FBXO45 is a Potential Therapeutic Target for Cancer Therapy. Cell Death Discovery (2020) 6:55. doi: 10.1038/s41420-0200291-2

92. Qin ZY, Wang T, Su S, Shen LT, Zhu GX, Liu Q, et al. BRD4 Promotes Gastric Cancer Progression and Metastasis Through Acetylation-Dependent Stabilization of Snail. Cancer Res (2019) 79:4869-81. doi: 10.1158/00085472.CAN-19-0442

93. Song L, Guo J, Chang R, Peng X, Li J, Xu X, et al. LKB1 Obliterates Snail Stability and Inhibits Pancreatic Cancer Metastasis in Response to Metformin Treatment. Cancer Sci (2018) 109:1382-92. doi: 10.1111/ cas. 13591

94. Komander D, Clague MJ, Urbe S. Breaking the Chains: Structure and Function of the Deubiquitinases. Nat Rev Mol Cell Biol (2009) 10:550-63. doi: $10.1038 / \mathrm{nrm} 2731$

95. Cheng J, Guo J, North BJ, Wang B, Cui CP, Li H, et al. Functional Analysis of Deubiquitylating Enzymes in Tumorigenesis and Development. Biochim Biophys Acta Rev Cancer (2019) 1872:188312. doi: 10.1016/ j.bbcan.2019.188312

96. Wei R, Liu X, Yu W, Yang T, Cai W, Liu J, et al. Deubiquitinases in Cancer. Oncotarget (2015) 6:12872-89. doi: 10.18632/oncotarget.3671

97. Tanguturi P, Kim KS, Ramakrishna S. The Role of Deubiquitinating Enzymes in Cancer Drug Resistance. Cancer Chemother Pharmacol (2020) 85:627-39. doi: 10.1007/s00280-020-04046-8

98. Herhaus L, Al-Salihi M, Macartney T, Weidlich S, Sapkota GP. OTUB1 Enhances TGFbeta Signalling by Inhibiting the Ubiquitylation and Degradation of Active SMAD2/3. Nat Commun (2013) 4:2519. doi: 10.1038/ncomms3519

99. Zhou H, Liu Y, Zhu R, Ding F, Cao X, Lin D, et al. OTUB1 Promotes Esophageal Squamous Cell Carcinoma Metastasis Through Modulating Snail Stability. ONCOGENE (2018) 37:3356-68. doi: 10.1038/s41388-0180224-1

100. Li L, Zhou H, Zhu R, Liu Z. USP26 Promotes Esophageal Squamous Cell Carcinoma Metastasis Through Stabilizing Snail. Cancer Lett (2019) 448:5260. doi: 10.1016/j.canlet.2019.02.007

101. Ning B, Zhao W, Qian C, Liu P, Li Q, Li W, et al. USP26 Functions as a Negative Regulator of Cellular Reprogramming by Stabilising PRC1 Complex Components. Nat Commun (2017) 8:349. doi: 10.1038/s41467017-00301-4

102. Guo X, Zhu R, Luo A, Zhou H, Ding F, Yang H, et al. EIF3H Promotes Aggressiveness of Esophageal Squamous Cell Carcinoma by Modulating Snail Stability. J Exp Clin Cancer Res (2020) 39:175. doi: 10.1186/s13046-02001678-9

103. Zhu R, Liu Y, Zhou H, Li L, Li Y, Ding F, et al. Deubiquitinating Enzyme PSMD14 Promotes Tumor Metastasis Through Stabilizing SNAIL in Human
Esophageal Squamous Cell Carcinoma. Cancer Lett (2018) 418:125-34. doi: 10.1016/j.canlet.2018.01.025

104. Wu Y, Wang Y, Lin Y, Liu Y, Wang Y, Jia J, et al. Dub3 Inhibition Suppresses Breast Cancer Invasion and Metastasis by Promoting Snail1 Degradation. Nat Commun (2017) 8:14228. doi: 10.1038/ncomms14228

105. Watanabe K, Yokoyama S, Kaneto N, Hori T, Iwakami Y, Kato S, et al. COP9 Signalosome Subunit 5 Regulates Cancer Metastasis by Deubiquitinating SNAIL. Oncotarget (2018) 9:20670-80. doi: 10.18632/oncotarget.25060

106. Cai J, Li M, Wang X, Li L, Li Q, Hou Z, et al. USP37 Promotes Lung Cancer Cell Migration by Stabilizing Snail Protein via Deubiquitination. Front Genet (2019) 10:1324. doi: 10.3389/fgene.2019.01324

107. Fan L, Chen Z, Wu X, Cai X, Feng S, Lu J, et al. Ubiquitin-Specific Protease 3 Promotes Glioblastoma Cell Invasion and Epithelial-Mesenchymal Transition via Stabilizing Snail. Mol Cancer Res (2019) 17:1975-84. doi: 10.1158/1541-7786.MCR-19-0197

108. Xu L, Li J, Bao Z, Xu P, Chang H, Wu J, et al. Silencing of OTUB1 Inhibits Migration of Human Glioma Cells In Vitro. Neuropathology (2017) 37:21726. doi: 10.1111/neup. 12366

109. Choi BJ, Park SA, Lee SY, Cha YN, Surh YJ. Hypoxia Induces EpithelialMesenchymal Transition in Colorectal Cancer Cells Through UbiquitinSpecific Protease 47-Mediated Stabilization of Snail: A Potential Role of Sox9. Sci Rep (2017) 7:15918. doi: 10.1038/s41598-017-15139-5

110. Qian W, Li Q, Wu X, Li W, Li Q, Zhang J, et al. Deubiquitinase USP29 Promotes Gastric Cancer Cell Migration by Cooperating With Phosphatase SCP1 to Stabilize Snail Protein. Oncogene (2020) 39:6802-15. doi: 10.1038/ s41388-020-01471-0

111. Hogg SJ, Beavis PA, Dawson MA, Johnstone RW. Targeting the Epigenetic Regulation of Antitumour Immunity. Nat Rev Drug Discovery (2020) 19:776-800. doi: 10.1038/s41573-020-0077-5

112. Dawson MA, Kouzarides T. Cancer Epigenetics: From Mechanism to Therapy. Cell (2012) 150:12-27. doi: 10.1016/j.cell.2012.06.013

113. Baylin SB, Herman JG. DNA Hypermethylation in Tumorigenesis: Epigenetics Joins Genetics. Trends Genet (2000) 16:168-74. doi: 10.1016/ s0168-9525(99)01971-x

114. Chen Y, Wang K, Qian CN, Leach R. DNA Methylation Is Associated With Transcription of Snail and Slug Genes. Biochem Biophys Res Commun (2013) 430:1083-90. doi: 10.1016/j.bbrc.2012.12.034

115. Jiang H, Cao HJ, Ma N, Bao WD, Wang JJ, Chen TW, et al. Chromatin Remodeling Factor ARID2 Suppresses Hepatocellular Carcinoma Metastasis via DNMT1-Snail Axis. Proc Natl Acad Sci U S A (2020) 117:4770-80. doi: 10.1073/pnas.1914937117

116. Liu ZX, Li LM, Sun HL, Liu SM. Link Between M6a Modification and Cancers. Front Bioeng Biotechnol (2018) 6:89. doi: 10.3389/fbioe.2018.00089

117. Sun T, Wu R, Ming L. The Role of M6a RNA Methylation in Cancer. BioMed Pharmacother (2019) 112:108613. doi: 10.1016/j.biopha.2019.108613

118. Li J, Chen F, Peng Y, Lv Z, Lin X, Chen Z, et al. N6-Methyladenosine Regulates the Expression and Secretion of TGFbetal to Affect the EpithelialMesenchymal Transition of Cancer Cells. CELLS-BASEL (2020) 9:296. doi: $10.3390 /$ cells 9020296

119. Guo P, Chen W, Li H, Li M, Li L. The Histone Acetylation Modifications of Breast Cancer and Their Therapeutic Implications. Pathol Oncol Res (2018) 24:807-13. doi: 10.1007/s12253-018-0433-5

120. Narita T, Weinert BT, Choudhary C. Functions and Mechanisms of NonHistone Protein Acetylation. Nat Rev Mol Cell Biol (2019) 20:156-74. doi: 10.1038/s41580-018-0081-3

121. Zhang J, Jia L, Liu T, Yip YL, Tang WC, Lin W, et al. Mtorc2-Mediated PDHE1alpha Nuclear Translocation Links EBV-LMP1 Reprogrammed Glucose Metabolism to Cancer Metastasis in Nasopharyngeal Carcinoma. Oncogene (2019) 38:4669-84. doi: 10.1038/s41388-019-0749-y

122. Ren X, Yang X, Cheng B, Chen X, Zhang T, He Q, et al. HOPX Hypermethylation Promotes Metastasis via Activating SNAIL Transcription in Nasopharyngeal Carcinoma. Nat Commun (2017) 8:14053. doi: $10.1038 /$ ncomms14053

123. Chang R, Zhang Y, Zhang P, Zhou Q. Snail Acetylation by Histone Acetyltransferase P300 in Lung Cancer. Thorac Cancer (2017) 8:131-7. doi: 10.1111/1759-7714.12408

124. Hsu DS, Wang HJ, Tai SK, Chou CH, Hsieh CH, Chiu PH, et al. Acetylation of Snail Modulates the Cytokinome of Cancer Cells to Enhance the 
Recruitment of Macrophages. Cancer Cell (2014) 26:534-48. doi: 10.1016/ j.ccell.2014.09.002

125. West AC, Johnstone RW. New and Emerging HDAC Inhibitors for Cancer Treatment. J Clin Invest (2014) 124:30-9. doi: 10.1172/JCI69738

126. Lakshmaiah KC, Jacob LA, Aparna S, Lokanatha D, Saldanha SC. Epigenetic Therapy of Cancer With Histone Deacetylase Inhibitors. J Cancer Res Ther (2014) 10:469-78. doi: 10.4103/0973-1482.137937

127. Xu W, Liu H, Liu ZG, Wang HS, Zhang F, Wang H, et al. Histone Deacetylase Inhibitors Upregulate Snail via Smad2/3 Phosphorylation and Stabilization of Snail to Promote Metastasis of Hepatoma Cells. Cancer Lett (2018) 420:1-13. doi: 10.1016/j.canlet.2018.01.068

128. Jiang GM, Wang HS, Zhang F, Zhang KS, Liu ZC, Fang R, et al. Histone Deacetylase Inhibitor Induction of Epithelial-Mesenchymal Transitions via Up-Regulation of Snail Facilitates Cancer Progression. Biochim Biophys Acta (2013) 1833:663-71. doi: 10.1016/j.bbamcr.2012.12.002

129. Lei X, Lei Y, Li JK, Du WX, Li RG, Yang J, et al. Immune Cells Within the Tumor Microenvironment: Biological Functions and Roles in Cancer Immunotherapy. Cancer Lett (2020) 470:126-33. doi: 10.1016/j.canlet. 2019.11.009

130. Arneth B. Tumor Microenvironment. Med (Kaunas) (2019) 56:15. doi: 10.3390/medicina56010015

131. Li B, Chan HL, Chen P. Immune Checkpoint Inhibitors: Basics and Challenges. Curr Med Chem (2019) 26:3009-25. doi: 10.2174/ 0929867324666170804143706

132. Han Y, Liu D, Li L. PD-1/PD-L1 Pathway: Current Researches in Cancer. Am $J$ Cancer Res (2020) 10:727-42.

133. Yi M, Jiao D, Xu H, Liu Q, Zhao W, Han X, et al. Biomarkers for Predicting Efficacy of PD-1/PD-L1 Inhibitors. Mol Cancer (2018) 17:129. doi: 10.1186/ s12943-018-0864-3

134. Kim S, Koh J, Kim MY, Kwon D, Go H, Kim YA, et al. PD-L1 Expression is Associated With Epithelial-to-Mesenchymal Transition in Adenocarcinoma of the Lung. Hum Pathol (2016) 58:7-14. doi: 10.1016/j.humpath.2016.07.007

135. Chen C, Li S, Xue J, Qi M, Liu X, Huang Y, et al. PD-L1 Tumor-Intrinsic Signaling and Its Therapeutic Implication in Triple-Negative Breast Cancer. JCI Insight (2021) 6:e131458. doi: 10.1172/jci.insight.131458

136. Wang S, Li J, Xie J, Liu F, Duan Y, Wu Y, et al. Programmed Death Ligand 1 Promotes Lymph Node Metastasis and Glucose Metabolism in Cervical Cancer by Activating Integrin Beta4/SNAI1/SIRT3 Signaling Pathway. Oncogene (2018) 37:4164-80. doi: 10.1038/s41388-018-0252-x

137. Monney L, Sabatos CA, Gaglia JL, Ryu A, Waldner H, Chernova T, et al. Th1-Specific Cell Surface Protein Tim-3 Regulates Macrophage Activation and Severity of an Autoimmune Disease. Nature (2002) 415:536-41. doi: $10.1038 / 415536 a$

138. Shang Y, Li Z, Li H, Xia H, Lin Z. TIM-3 Expression in Human Osteosarcoma: Correlation With the Expression of EpithelialMesenchymal Transition-Specific Biomarkers. Oncol Lett (2013) 6:490-4. doi: 10.3892/ol.2013.1410

139. Lin H, Yang B. Teng M. T-Cell Immunoglobulin Mucin-3 as a Potential Inducer of the Epithelial-Mesenchymal Transition in Hepatocellular Carcinoma. Oncol Lett (2017) 14:5899-905. doi: 10.3892/ol.2017.6961

140. Feng ZM, Guo SM. Tim-3 Facilitates Osteosarcoma Proliferation and Metastasis Through the NF-kappaB Pathway and Epithelial-Mesenchymal Transition. Genet Mol Res (2016) 15:10.4238/gmr.15037844. doi: 10.4238/ gmr.15037844

141. Shan B, Man H, Liu J, Wang L, Zhu T, Ma M, et al. TIM-3 Promotes the Metastasis of Esophageal Squamous Cell Carcinoma by Targeting EpithelialMesenchymal Transition via the Akt/GSK-3beta/Snail Signaling Pathway. Oncol Rep (2016) 36:1551-61. doi: 10.3892/or.2016.4938

142. Kudo-Saito C, Shirako H, Takeuchi T, Kawakami Y. Cancer Metastasis is Accelerated Through Immunosuppression During Snail-Induced EMT of Cancer Cells. Cancer Cell (2009) 15:195-206. doi: 10.1016/j.ccr.2009.01.023

143. Kudo-Saito C, Shirako H, Ohike M, Tsukamoto N, Kawakami Y. CCL2 is Critical for Immunosuppression to Promote Cancer Metastasis. Clin Exp Metastasis (2013) 30:393-405. doi: 10.1007/s10585-012-9545-6

144. Faget J, Groeneveld S, Boivin G, Sankar M, Zangger N, Garcia M, et al. Neutrophils and Snail Orchestrate the Establishment of a Pro-Tumor Microenvironment in Lung Cancer. Cell Rep (2017) 21:3190-204. doi: 10.1016/j.celrep.2017.11.052
145. Taki M, Abiko K, Baba T, Hamanishi J, Yamaguchi K, Murakami R, et al. Snail Promotes Ovarian Cancer Progression by Recruiting Myeloid-Derived Suppressor Cells via CXCR2 Ligand Upregulation. Nat Commun (2018) 9:1685. doi: 10.1038/s41467-018-03966-7

146. Gabrilovich DI. Myeloid-Derived Suppressor Cells. Cancer Immunol Res (2017) 5:3-8. doi: 10.1158/2326-6066.CIR-16-0297

147. Kumar V, Patel S, Tcyganov E, Gabrilovich DI. The Nature of MyeloidDerived Suppressor Cells in the Tumor Microenvironment. Trends Immunol (2016) 37:208-20. doi: 10.1016/j.it.2016.01.004

148. Qian Y, Yao W, Yang T, Yang Y, Liu Y, Shen Q, et al. aPKC-Iota/P-Sp1/Snail Signaling Induces Epithelial-Mesenchymal Transition and Immunosuppression in Cholangiocarcinoma. Hepatology (2017) 66:116582. doi: 10.1002/hep.29296

149. Hsieh CH, Tai SK, Yang MH. Snail-Overexpressing Cancer Cells Promote M2-Like Polarization of Tumor-Associated Macrophages by Delivering MiR-21-Abundant Exosomes. Neoplasia (2018) 20:775-88. doi: 10.1016/ j.neo.2018.06.004

150. Du F, Yang R, Ma HL, Wang QY, Wei SL. Expression of Transcriptional Repressor Slug Gene in Mouse Endometrium and Its Effect During Embryo Implantation. Appl Biochem Biotechnol (2009) 157:346-55. doi: 10.1007/ s12010-008-8521-8

151. Swain SD, Grifka-Walk HN, Gripentrog J, Lehmann M, Deuling B, Jenkins B, et al. Slug and Snail Have Differential Effects in Directing Colonic Epithelial Wound Healing and Partially Mediate the Restitutive Effects of Butyrate. Am J Physiol Gastrointest Liver Physiol (2019) 317:G531-44. doi: 10.1152/ajpgi.00071.2019

152. Liu W, Liu Y, Liu H, Zhang W, An H, Xu J. Snail Predicts Recurrence and Survival of Patients With Localized Clear Cell Renal Cell Carcinoma After Surgical Resection. Urol Oncol (2015) 33:69.e1-10. doi: 10.1016/j.urolonc.2014.08.003

153. Gou Y, Ding W, Xu K, Wang H, Chen Z, Tan J, et al. Snail is an Independent Prognostic Indicator for Predicting Recurrence and Progression in NonMuscle-Invasive Bladder Cancer. Int Urol Nephrol (2015) 47:289-93. doi: 10.1007/s11255-014-0874-z

154. Oh KY, Yoon HJ, Lee JI, Ahn SH, Hong SD. Twist and Snail Expression in Tumor and Stromal Cells of Epithelial Odontogenic Tumors. J Oral Pathol Med (2017) 46:127-33. doi: 10.1111/jop.12479

155. Wang G, Ma W, Li Y, Jiang Y, Ma G, Zhang X, et al. Prognostic Value of Twist, Snail and E-Cadherin Expression in Pathological N0 Non-Small-Cell Lung Cancer: A Retrospective Cohort Study. Eur J Cardiothorac Surg (2018) 54:237-45. doi: 10.1093/ejcts/ezy022

156. Rashed HE, Hussein S, Mosaad H, Abdelwahab MM, Abdelhamid MI, Mohamed SY, et al. Prognostic Significance of the Genetic and the Immunohistochemical Expression of Epithelial-Mesenchymal-Related Markers in Colon Cancer. Cancer Biomark (2017) 20:107-22. doi: 10.3233/CBM-170034

157. Zhao G, Kim KY, Zheng Z, Oh Y, Yoo DS, Lee ME, et al. AXIN2 and SNAIL Expression Predict the Risk of Recurrence in Cutaneous Squamous Cell Carcinoma After Mohs Micrographic Surgery. Oncol Lett (2020) 19:2133-40. doi: $10.3892 / 01.2020 .11324$

158. Kwon CH, Park HJ, Choi JH, Lee JR, Kim HK, Jo HJ, et al. Snail and Serpinal Promote Tumor Progression and Predict Prognosis in Colorectal Cancer. Oncotarget (2015) 6:20312-26. doi: 10.18632/oncotarget.3964

159. van Nes JG, de Kruijf EM, Putter H, Faratian D, Munro A, Campbell F, et al. Co-Expression of SNAIL and TWIST Determines Prognosis in Estrogen Receptor-Positive Early Breast Cancer Patients. Breast Cancer Res Treat (2012) 133:49-59. doi: 10.1007/s10549-011-1684-y

160. Mikami S, Katsube K, Oya M, Ishida M, Kosaka T, Mizuno R, et al. Expression of Snail and Slug in Renal Cell Carcinoma: E-Cadherin Repressor Snail is Associated With Cancer Invasion and Prognosis. Lab Invest (2011) 91:1443-58. doi: 10.1038/labinvest.2011.111

161. Shin NR, Jeong EH, Choi CI, Moon HJ, Kwon CH, Chu IS, et al. Overexpression of Snail is Associated With Lymph Node Metastasis and Poor Prognosis in Patients With Gastric Cancer. BMC Cancer (2012) 12:521. doi: 10.1186/1471-2407-12-521

162. Zheng X, Carstens JL, Kim J, Scheible M, Kaye J, Sugimoto H, et al. Epithelial-To-Mesenchymal Transition is Dispensable for Metastasis But Induces Chemoresistance in Pancreatic Cancer. Nature (2015) 527:525-30. doi: 10.1038/nature16064 
163. Richards KE, Zeleniak AE, Fishel ML, Wu J, Littlepage LE, Hill R. CancerAssociated Fibroblast Exosomes Regulate Survival and Proliferation of Pancreatic Cancer Cells. Oncogene (2017) 36:1770-8. doi: 10.1038/onc.2016.353

164. Wang H, Wang Z, Li Y, Lu T, Hu G. Silencing Snail Reverses EpithelialMesenchymal Transition and Increases Radiosensitivity in Hypopharyngeal Carcinoma. Onco Targets Ther (2020) 13:497-511. doi: 10.2147/OTT.S237410

165. Liang H, Chen G, Li J, Yang F. Snail Expression Contributes to Temozolomide Resistance in Glioblastoma. Am J Transl Res (2019) 11:4277-89.

166. Wang H, Li JM, Wei W, Yang R, Chen D, Ma XD, et al. Regulation of ATPBinding Cassette Subfamily B Member 1 by Snail Contributes to Chemoresistance in Colorectal Cancer. Cancer Sci (2020) 111:84-97. doi: $10.1111 /$ cas. 14253

167. Fan F, Samuel S, Evans KW, Lu J, Xia L, Zhou Y, et al. Overexpression of Snail Induces Epithelial-Mesenchymal Transition and a Cancer Stem CellLike Phenotype in Human Colorectal Cancer Cells. Cancer Med (2012) 1:516. doi: 10.1002/cam4.4

168. Li HM, Bi YR, Li Y, Fu R, Lv WC, Jiang N, et al. A Potent CBP/p300-Snail Interaction Inhibitor Suppresses Tumor Growth and Metastasis in WildType P53-Expressing Cancer. Sci Adv (2020) 6:eaaw8500. doi: 10.1126/ sciadv.aaw8500

169. Azmi AS, Bollig-Fischer A, Bao B, Park BJ, Lee SH, Yong-Song G, et al. Systems Analysis Reveals a Transcriptional Reversal of the Mesenchymal
Phenotype Induced by SNAIL-Inhibitor GN-25. BMC Syst Biol (2013) 7:85. doi: 10.1186/1752-0509-7-85

170. Harney AS, Meade TJ, LaBonne C. Targeted Inactivation of Snail Family EMT Regulatory Factors by a Co(III)-Ebox Conjugate. PloS One (2012) 7: e32318. doi: 10.1371/journal.pone.0032318

Conflict of Interest: The authors declare that the research was conducted in the absence of any commercial or financial relationships that could be construed as a potential conflict of interest.

Publisher's Note: All claims expressed in this article are solely those of the authors and do not necessarily represent those of their affiliated organizations, or those of the publisher, the editors and the reviewers. Any product that may be evaluated in this article, or claim that may be made by its manufacturer, is not guaranteed or endorsed by the publisher.

Copyright (c) 2021 Tang, Sui, Weng and Liu. This is an open-access article distributed under the terms of the Creative Commons Attribution License (CC BY). The use, distribution or reproduction in other forums is permitted, provided the original author(s) and the copyright owner(s) are credited and that the original publication in this journal is cited, in accordance with accepted academic practice. No use, distribution or reproduction is permitted which does not comply with these terms. 